reduced to less than 50 per cent of the initial level. In spite of deficient acetylcholinesterase during the period of investigation (50 days), erythrocyte life-span was within normal limits in all subjects (Table 1). In two further subjects OMPA was administered for a period of 21 days before labelling the erythrocytes. The life-span of the erythrocytes was within normal limits in both subjects (Table 1).

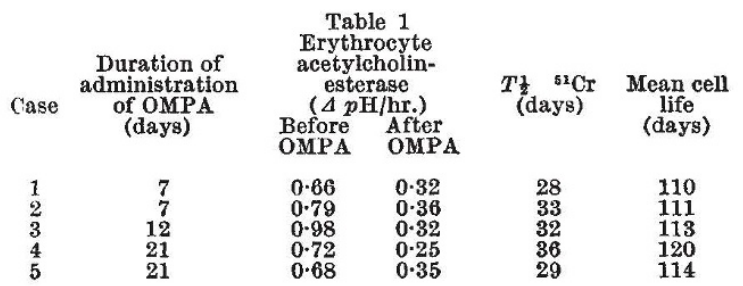

Thus in five subjects where erythrocyte acetylcholinesterase was inhibited to levels comparable to those found in patients with P.N.H., shortening of erythrocyte life-span could not be demonstrated. These results suggest that normal amounts of the enzyme are not essential for the maintenance of red. cell life-span, and that the low levels of enzyme in P.N.H. do not directly contribute to the diminished erythrocyto life-span in the disease.

We wish to thank the Director, South African Institute for Medical Research, for facilities to carry out this work.

$$
\begin{aligned}
& \text { J. Metz } \\
& \text { N. J. VAN RensburG } \\
& \text { K. Stevens } \\
& \text { D. Hart }
\end{aligned}
$$

South African Institute for Medical Research, P.O. Box 1038, Johannesburg.

${ }^{1}$ Greig, M. E., and Holland, W. C., Arch. Biochem., 23, 370 (1949).

${ }^{2}$ Auditore, J. V., Hartmann, R. C., and Cole, E. F., J. Clin. Invest. 38, 702 (1959).

${ }^{3}$ De Sandre, G., Ghiotto, G., and Mastella, G., Acta med. patav., 16, 310 (1956).

- Metz, J., Bradlow, B. A., Lewis, S. M., and Dacie, J. V., Brit. J. Hcemat., 8, $372(1960)$.

' Frawley, J. P., Hagan, E. C., and Fitzhugh, O. G., J. Pharmacol. 105, 156 (1952)

${ }^{6}$ Michel, H. O., J. Lab. Clin. Med., 34, 1564 (1949).

'Mollison, P. L., and Veall, N., Brit. J. Hcomat., 1, 62 (1955).

\section{Fructose as a Component of the Fotal Blood in Several Mammalian Species}

Is the examination of foetal bloods from several mammalian species, Goodwin ${ }^{1}$ suggested that fructose is a characteristic component of the fotal blood of the Ungulata and Cetacea. We wish to support this generalization by reporting the presence of fructose in the fotal blood and foetal fluids of several further species within the order Ungulata, and the essential absence in a member of the Edentata.

The specimens from the dromedary were made available through Dr. W. R. M. Morton, of the Queen's University, Belfast, the sloth material obtained while one of us (A. St. G. H.) was in Brazil, through the kindness of Prof. Nelson Chaves, of the University of Recife. The remainder of the specimens were obtained by Mr. Tong and his staff at Whipsnade Zoological Park. Samples were obtained from the placenta at a variable interval of time after extrusion. The material was placed in bottles containing 100 mgm. powdered sodium fluoride and potessium oxalate in the ratio $1: 3$ and refrigerated pending transfer to the laboratory. After deproteinization, the filtrates were estimated for glucose and fructose by the glucose oxidase and resorcinol methods respectively. The concentrations obtained (Table 1 ) must be considered as minimal values, since there is evidence of a preferential utilization of glucose in the placenta after it is shed.

It is interesting perhaps to note that in the spectrum of mammalian species which have been examined by us and by others ${ }^{2-4}$, in which fructose is present in substantial concentrations, all belong to a group of animals having either the epitheliochorial or syndesmochorial type of placenta. The latter type, typified by the sheep, is known from direct experimentation to produce fructose ${ }^{5}$.

Physiology Department,

A. Sr. G. HugGetr

D. A. Nrxon

St. Mary's Hospital Medical School, London, W.2.

${ }^{1}$ Goodwin, R. F. W., J. Physiol., 132, 146 (1956)

${ }^{2}$ Ainsworth, I. B., Parr, C. W., and Warren, F. I., J. Endocrinol., 7 , lxiii (1951).

${ }^{3}$ Huggett, A. St. G., J, Physiol, 146, 53 P (1959).

- Walker, D. G., Nature, 173, 309 (1954)

Alexander, D. P., Huggett, A. St. G., Nixon, D. A., and Widdas, W. F., J. Physiol., 129, 367 (1955).

\section{Transferrin-groups of Fœtal Calf-Serum}

INTENSIVE work on the occurrence of blood-group factors in embryos of cattle ${ }^{1}$ led to the result that the pattern of blood-group factors, as special individual molecule structures, are genetically dependent and, consequently, are already fixed in the mother cells of the erythropoietic system. The substances of the blood groups undergo a maturing process before birth during embryonic and foetal growth. With the help of strong immunosera, the blood-group factors already

\begin{tabular}{|c|c|c|c|c|c|c|}
\hline \multirow[b]{2}{*}{ Species } & \multirow{2}{*}{\multicolumn{2}{|c|}{$\begin{array}{c}\text { Maternal blood } \\
\text { Glucose }\end{array}$}} & \multicolumn{2}{|c|}{ Fotal blood } & \multicolumn{2}{|c|}{ Fcotal fluids* } \\
\hline & & & Glucose & Fructose & Ghucose & ructose \\
\hline Père David's deer (Elaphurus davidianus) & - & 一 & 364 & 61 & 12 & 209 \\
\hline Père David's deer (Elaphurus davidianus) & 二 & - & 18 & 57 & 22 & 36 \\
\hline $\begin{array}{l}\text { Huanaco (Lama huanacus) } \\
\text { Llama (domestic breed) }\end{array}$ & $\overline{-}$ & $\Xi$ & $\begin{array}{l}32 \\
15\end{array}$ & & 14 & 218 \\
\hline $\begin{array}{l}\text { Llama (domestic breed) } \\
\text { Giraffe (Giraffa camalopardalis) }\end{array}$ & - & 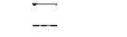 & 8 & $\begin{array}{r}43 \\
8\end{array}$ & 10 & 223 \\
\hline Rhinoceros (Rhinoceros unicornis) & 一 & - & 15 & 31 & 二 & 二 \\
\hline Hippopotamus (Hippopotamus amphibius) & $=$ & - & 9 & 60 & - & - \\
\hline Bactrian camel (Camelus bactrianus) & 二 & 二 & $-{ }_{9}$ & 84 & $\overline{12}$ & $\overline{270}$ \\
\hline Bactrian camel (Camelus bactrianus) & - & - $\mathbf{U A} \dagger$ & 42 & $\begin{array}{l}63 \\
40\end{array}$ & 13 & 376 \\
\hline Dromedary camel (Camelus dromedarius) & 97 & ${ }^{0} \mathrm{UV}+$ & & 41 & 6 & 352 \\
\hline Three-toed sloth (Bradypus tridactylus) & 124 & 1.5 & 28 & $1 \cdot 5$ & 13 & $1 \cdot 5$ \\
\hline
\end{tabular}
can be identified in the early embryonic stage in the immuno-hæmolytic and in the inhibition test. The

Table 1. Glucose and Frudtose Concentrations in Samples obTained from Species within the ORders Ungulata and Edentata

* Amniotic or allantoic or a mixture of both fluids.

$\dagger \mathrm{UA}$ and $\mathrm{UV}$ refer to umbilical artery and vein samples respectively. 